International Journal of Agriculture, Environment and Bioresearch

Vol. 5, No. 01; 2020

ISSN: $2456-8643$

\title{
USE OF HYDROPONIC GREEN FODDER IN SHEEP MEAT BREEDING AND PRODUCTION IN THE SOUSS MASSA REGION (SOUTH OF MOROCCO): PRELIMINARY STUDY
}

\author{
Bari S. ${ }^{1}$, Hikamat A. ${ }^{1}$, Kaaya A. ${ }^{1}$, El Moukhtari A. ${ }^{2}$ and Mannas H. ${ }^{1}$ \\ ${ }^{1}$ Bio Environment, Health and Bioresources team, Faculty of Sciences, Ibn University Zohr, Agadir, Morocco \\ ${ }^{2}$ Souss Cooperative of Bovine Genetic Improvement (SAGB), Taroudant, Morocco
}

https://doi.org/10.35410/IJAEB.2020.5482

\begin{abstract}
The aim of this work was i) to assess whether the Green Hydroponic Forage (GHF) can constitute an interesting fodder supplement for fattening lambs and ii) to determine the effect of the introduction of GHF at $30 \%$ of the theoretical fodder requirement in the ration on the consumption and performance of lambs. The GHF production unit (Capacity: 1 ton / day each) was set up on the farm of the Agricultural Cooperative (Copag) (Province of Taroudant). Over a 2-month fattening period, a feed trial was carried out on two lots of 20 ewe lambs of improved breed.
\end{abstract}

Our preliminary results show that it is a very palatable fodder and quickly accepted by animals. The GHF batch had a lower hay consumption than that of the control (-30\%), up to the dry matter (DM) provided by the GHF. Higher growth performances were noted in the Test batch. Furthermore, this fodder can be introduced into the ration of lambs during the fattening period to improve their performance

Keywords: Green Hydroponic Forage (GHF), Agricultural Cooperative , Dry Matter.

\section{INTRODUCTION}

In the Souss Massa Region (South of Morocco), the "sheep meat" sector is facing challenges hampering its growth. In fact, not being a cradle of sheep breeds, it does not benefit from any genetic improvement program capable of enhancing it. In addition, the overexploitation of the water table forces farmers to turn to profitable crops, this limits the supply of fodder which hinders the growth of livestock.

In this context, the production of above-ground fodder would constitute an alternative to the fodder deficit and the economy of water. In fact, the Regional Agricultural Plan (PAR) launched, in partnership with the Regional Association of Sheep Breeders of Souss Massa, a project for the development of sheep farming with a main component which integrates the production of Green Hydroponic Forage (GHF) and genetic improvement and support and supervision actions.

To ensure its sufficient profitability capable of lasting sustainability in the Souss Massa Region, the sheep sector has set itself the objective of increasing livestock productivity by $40 \%$ by 2021 . To achieve this, it was necessary to ensure local fodder production in line these objectives. 
However, forage production in the plain repeatedly suffers from irregularities in the quantity and quality produced during the year. This fodder deficit has been exacerbated in recent years by increasingly frequent episodes of drought and by the overexploitation of the water table. In fact, the semi-arid climate, which characterizes the region (with more than 3000 hours of sunshine), increasingly directs producers towards crops with high added value (Market gardening: 70\% of national production and almost $90 \%$ of exports; Citrus: $50 \%$ of national production and nearly $70 \%$ of exports). These constraints, which are expected to become more and more pronounced in the coming years, make it necessary to ensure and secure fodder production in the medium and long term.

In this context, the profession is strongly mobilized to find ways of diversification, with the introduction of forage crops that are less water-demanding, the importation of fodder, the exploitation of agro-industry by-products and very recently individual tests of the use of aboveground fodder production techniques. The latter, based on the principle of germinated seed, make it possible to grow carpets of young fodder plants in the trays and to obtain in a short time (7 to 10 days) a large biomass and of constant quality (Sneath and McIntosh, 2003).

The production of above-ground fodder could be considered as an alternative for the Souss Massa Region. In fact, it represents a way of intensifying the production of green fodder in constant quantity and quality throughout the year (Cuddeford, 1989) and seems to be interesting for the fattening sector of ruminants in general and sheep in particular (Chavan and Kadam, 1989).

In addition, the animal and sheep herd in particular has few forage areas, and the feed is mainly based on hay, which the food quality remains very heterogeneous (Rodrigues et al, 2004; Reddy, 2014). In fact, the number of sheep in the Souss Massa went from 450,000 head in 2009 to 407,600 head in 2016, a reduction of almost $10 \%$ since the launch of the Morocco plan. The development of the GHF could thus improve the autonomy of the livestock and guarantee a stability of its workforce which constitutes the main obstacle to the launching of genetic improvement programs capable of improving the productivity of the existing livestock. In this context, the present work aims to study the effect of feeding hydroponic green fodder on the performance of lambs.

\section{MATERIALS AND METHODS}

\section{Study site}

The experimental trial was carried out at the farm of the Agricultural Cooperative (COPAG) in the province of Taroudant belonging to the locality of Souss Massa in southwest of Morocco (Figure 1). 


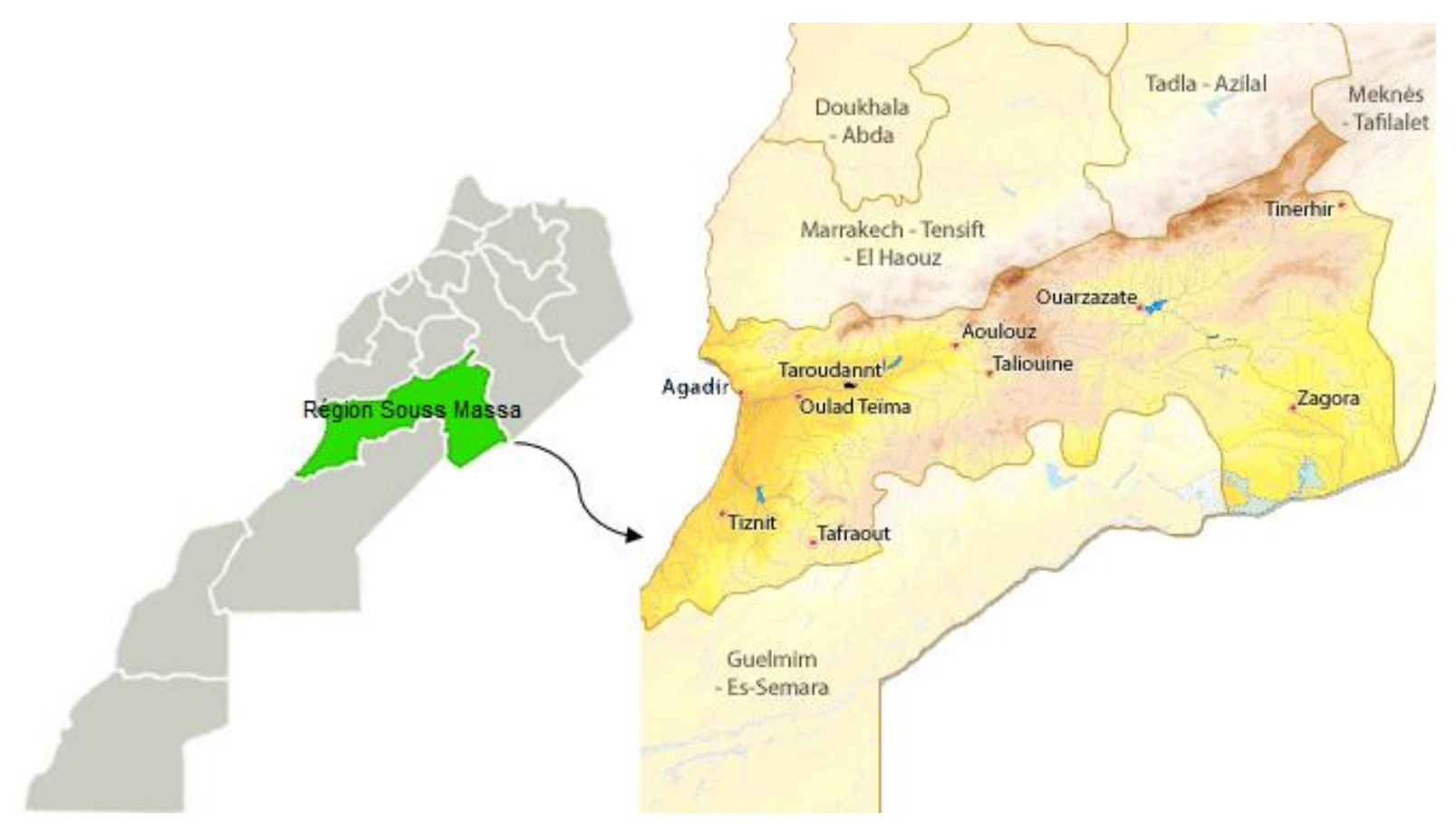

Figure 1: Map showing the location of the Province of Taroudant in the Souss Massa Region

The cooperative has a fattening farm for local breed sheep backed by a slaughterhouse as part of an integrated project including fattening workshop, slaughterhouse, cutting room and delicatessen with a capacity of 20,000 heads per year. The capacity of the fattening unit is 3000 heads of different ages and weights to ensure a continuous supply to the slaughterhouse. The animals enter the fattening workshop at the age of 3 to 4 months and with an average live weight of 18 to $20 \mathrm{Kg}$.

\section{GHF Production}

The green hydroponic fodder (GHF) used is obtained from malting barley seeds (local variety, with $90 \%$ germination rate). The seeds used are first cleaned and disinfected with sodium hypochlorite $(1 \mathrm{ml} / \mathrm{l})$. After rinsing with potable water, they are soaked in fresh water for 16 to 18 hours then drained before being sown for cultivation at a density of $7 \mathrm{~kg} / \mathrm{m}^{2}$. The culture takes place in a closed culture chamber (Model E-12-TX) with an area of $92 \mathrm{~m}^{2}$. Temperature, humidity and lighting are controlled $\left(18 \pm 1.5^{\circ} \mathrm{C}, 60-100 \% \mathrm{H}\right.$ and 12 hours a day $(58 \mathrm{~W}$ fluorescent lamps) respectively). The culture is irrigated by immersion twice a day $(2 \pm 0.11 / \mathrm{kg}$ Raw Material). The harvest is carried out at the seedling stage at $7 \pm 1$ day. The yield generally observed is $6.01 \pm 0.10 \mathrm{Kg}$ of green fodder produced per $\mathrm{Kg}$ of dry germinated grain at 12$13.5 \%$ dry matter.

\section{Food trial}

The present study carried out on the Copag cooperative farm reports and analyzes the growth performance of 220 lambs of the age around three months and were fattened for 159 days during 
the period from 11/07 to 15/10/2017. The animals were housed in semi-open greenhouses and subjected to two fattening diets based on alfalfa hay and straw: i) a control diet without hydroponic barley (Control batch: Alfalfa hay and straw "at will" and concentrated for sheep) and ii) a GHF diet with hydroponic barley (GHF batch: $30 \%$ of theoretical fodder requirements in the form of GHF of $7 \pm 1$ days). Each group consisted of 110 lambs. The animals are randomly assigned to one of two treatment diets. The hay and the straw were brought to them at will and the concentrate was rationed according to the usual practices of the breeder at equivalent dose for the two lots. The GHF was added in addition to the basic ration "Hay and Straw", as a fodder supplement while keeping practically the same energy and protein concentration for the two rations (Table 1).

Table 1: Feed rations for ewe lambs during the test

DM: Dry Matter, DQ: Daily Quantity, GM: Gross Matter, UFVMeat Fodder Unit.

\begin{tabular}{|lll|l|l|l|l|l|}
\cline { 2 - 8 } \multicolumn{1}{c|}{} & \multicolumn{5}{l}{ Control } & \multicolumn{2}{l}{ GHF diet } \\
\cline { 2 - 8 } \multicolumn{1}{c|}{} & DQ en GM Kg & DM Kg & UFV & DQ en GM Kg & DM Kg & UFV \\
\hline Alfalfa hay & 0,35 & 0,3 & 0,2 & 0,1 & 0,09 & 0,06 \\
\hline Hydroponic barley & 0 & 0 & 0 & 2,25 & 0,29 & 0,26 \\
\hline Straw & 0,35 & 0,3 & 0,12 & 0,35 & 0,3 & 0,09 \\
\hline Flaked Corn & 0,45 & 0,4 & 0,5 & 0,35 & 0,31 & 0,39 \\
\hline Concentrate & 0,15 & 0,13 & 0,13 & 0,15 & 0,13 & 0,13 \\
\hline $\begin{array}{l}\text { Vitamin } \\
\text { supplement }\end{array}$ & 0,05 & - & - & 0,05 & - & - \\
\hline Total & 1,35 & 1,12 & 0,95 & 3,25 & 1,12 & 0,93 \\
\hline
\end{tabular}

\section{Analyzes performed}

\section{Hydroponic barley analyzes}

Samples of hydroponic barley used in our test were collected and dried in an oven at $70{ }^{\circ} \mathrm{C}$ for 48 hours and then weighed before being analyzed; we have adopted the analysis methods recommended by AOAC 2000 (the Association of Official Analytical Chemists) which are also those recommended by the FAO. An approximate analysis of the samples taken was carried out and the total nitrogenous contents (TNC), Cellulose, fat (F), Moisture (M), and dry matter (DM) were determined. The acid detergent fiber (ADF) and neutral detergent fiber (NDF) contents have also been determined (Robertson and Van Soest, 1981; Van Soest et al., 1991) (Table 2). 
Table 2: Chemical composition of hydroponic barley used in the test

\begin{tabular}{|l|l|}
\hline Parameters (\%) & GHF \\
\hline Dry Matter (DM) & 13,7 \\
\hline Total NitrogenContent (TNC) & 13,3 \\
\hline Neutral Detergent Fiber (NDF) & 35,2 \\
\hline Acid Detergent Fiber (ADF) & 18,7 \\
\hline Fat & 2,7 \\
\hline Moisture rate (M) & 87,5 \\
\hline
\end{tabular}

Measurements made on animals

- Live weight

During the fattening period, the lambs were weighed in the morning on an empty stomach at the start and at the end of the study using a weight scale of $200 \mathrm{~kg} \pm 0.1 \mathrm{~kg}$.

\section{- Average Daily Gain}

Average Daily Gain (ADG) indicates the speed of growth of the animal over a period of time. It was calculated as follows:

$$
\operatorname{ADG}(\mathrm{g} / \mathrm{d})=(\mathrm{WF}-\mathrm{WI})^{*} 1000 / \mathrm{PT}
$$

with: $\mathrm{Wf}=$ Final Weight; $\mathrm{Wi}=$ Initial Weight; $\mathrm{PT}=$ Duration of the interval in two weighing in days .

\section{Statistical analysis}

The statistical analysis was performed using R 3.6.2 software.The T-test with Welch's approximation (WelchTwoSample t-test) and single factor ANOVA test were used to analyze the significance of the results. The materiality threshold was set at a probability of $5 \%$.

\section{RESULTS AND DISCUSSION}

In addition to the reasons related to the forage and water deficit in the Souss Massa Region, our interest in the use of hydroponic barley lies in its high nutritional value and its richness in amino acids, vitamins, enzymes and soluble carbohydrates (Lorenz and D'appalonia, 1989; Chavan and Kadam 1989). To better exploit the dietary characteristics of the green hydroponic fodder (GHF) in our study, a trial was conducted by feeding lambs with two feeding diets based on alfalfa hay and straw. The first diet without GHF (control diet), and the second diet containing green hydroponic fodder (GHF diet) to study its effect on lamb growth. Table 3 shows the measured parameters reflecting the lamb's growth performance that has been affected by the different diets. A combination of hydroponic barley and common wheat straw has been recommended at $60 / 40 \%$. This combination was given gradually to animals to reach a level of $2.25 \mathrm{Kg} / \mathrm{lamb} / \mathrm{day}$ (40\% of the total feed consumption (DM)).

Our observations revealed that this diet was quickly accepted by animals (2-3 days) and no refusals were observed. The consumption of straw was of the order of $0.35 \mathrm{Kg}$ of $\mathrm{GM} / \mathrm{day}$ for the two lots of lambs. The same trend was observed for the compound feed $(0.15 \mathrm{~kg} \mathrm{GM} /$ day), while for the vitamin mineral concentrate $(0.05 \mathrm{Kg} \mathrm{GM} /$ day) (Table 1$)$, only daily quantity supplied for alfalfa hay and flaked corn has changed between the trial GHF diet and the control diet in order 
to guarantee a relatively identical energy and protein concentration in the diet between the two groups. Likewise, the two lots received practically the same amount of dry fodder material. The germination of barley results in a loss of around $20-25 \%$ of dry matter, that is, nutrients, which is normal since the seedling used the grain reserves for its own synthesis (Demarquilly, 1987).

The moisture content of germinated barley is much higher (11.5\% dry matter) than that of barley's grain ( $89 \%$ dry matter) (Demarquilly, 1987). The mobilization of seed reserves for root growth significantly increases cellulose, ADF and NDF levels (Bhise et al, 1988).

Our results show that GHF provides a daily energy intake of $0.93 \mathrm{MFU}$ (Meat Fodder Unit), compared to $0.95 \mathrm{MFU}$ for control diet (Table1), a deficit of $2 \%$. Its nitrogen intake is $75.8 \mathrm{~g} \mathrm{DN}$ of (digestible nitrogen), compared to $78.8 \mathrm{~g}$ digestible nitrogen for the control lot, with a deficit of $4 \%$. This increase in the proportion of soluble nitrogen reflects the proteolysis of endosperm proteins with release of free amino acids, some of which (including glutamic acid and proline) serve as a nitrogen source for the amino acid synthesis of the embryo (Demarquilly, 1987).

The trials carried out by MirallesBrunean et al., (2015) show that GHF was consumed differently depending on its proportion in the ration. Beyond $25 \%$ of the fodder requirements covered by the GHF, a reduction in hay consumption has been observed $(-31 \%)$ for the batch of lambs.

The results of the analysis of the growth performance of ewe lambs from the two test batches show that animals growth parameters appear to be affected by the diets tested (Table 3 ).

Table 3: Growth performances of local ewe lambs fed on concentrated diets with (GHF) and without hydroponic barley (Control)

\begin{tabular}{|l|l|l|l|l|}
\hline & GHF & Control & SD & P-value \\
\hline Initial Weight (Kg) & 42,30 & 42,70 & 4,75 & $0,998 \mathrm{n}$ \\
\hline Final Weight (Kg) & 50,40 & 47,90 & 5,79 & 0,014 \\
\hline Total gain (Kg) & 8,10 & 5,20 & 2,11 & 0,000 \\
\hline Average Daily Gain (ADG) (Kg/d) & 0,27 & 0,17 & 0,07 & 0,000 \\
\hline
\end{tabular}

At the start of the test, the control and GHF batches had an average weight of $42.3 \mathrm{~kg}$ and 42.1 $\mathrm{kg}$ (Table 3), this difference was not significant $(\mathrm{p}=0.998)$. On the other hand, the final weight of the lambs fed on the GHF diet was higher ( $\mathrm{p}<0.05$ ) with $50.4 \mathrm{~kg}$ compared to $47.9 \mathrm{~kg}$ for the GHF and control lotrespectively. The total gain (final body weight - initial body weight) was significantly higher $(\mathrm{p}<0.05$ ) for lambs fed the GHF diet with $8.10 \mathrm{~kg}$, compared to lambs fed the control diet with $5.20 \mathrm{~kg}$.

During the study, the average daily gain (ADG) of the GHF batch was $0.27 \mathrm{Kg} /$ day, compared to $0.17 \mathrm{Kg} /$ day for the control. There is a difference of $0.10 \mathrm{Kg}$ in the benefit of the GHF lot which is significant $(\mathrm{p}<0.05)$ (Table 3 ). This difference between the two lots suggests that there is a better assimilation and valorization of the ration for the GHF lots. Most of the studies conducted by feeding animals with GHF have shown similar results to our study. 
Gebremedhin, (2015) reported that feeding hydroponic barley increases total dry matter absorption, feed conversion index and body weight gain compared to concentrated diets of growing goats. Similar results were also described by Fayed (2011) who showed that adding hydroponic barley to the diet improves the growth performance of lambs.

Furthermore, Intissaret Eshtayeh (2004) described this positive growth trend associated with an improvement in milk performance when incorporating hydroponic barley into a diet based on olive pomace in the Awessi dairy breed in Jordan. A positive effect of the incorporation of GHF in the feeding of lambs has also been described by Ata et al (2016). Such a tendency would be attributed to the richness of hydroponic barley in bioactive enzymes and in ingredients which would be responsible for the improvement of livestock performance (Naiket al., 2014) and shows that GHF could be very beneficial for farmers to increase the performance of their livestock.

According to our results, the lambs in the trial lot appeared more and more lively and dynamic with an improvement in their general appearance, with mainly more wool and less health problems (Reduction of digestive complications by 55\%). Hydroponic barley is a less acidogenic feed with a good energy and protein concentration (Chung et al., 1989).

Fattening tests carried out by MirallesBrunean et al., (2015) show that the ruminal $\mathrm{pH}$ of the GHF batch is constant while that of the control batch decreases (- 1 point), to reach a value which may present a risk of acidosis (> 5.5). Therefore, it would be wise to evaluate this forage in order to see its impact on the risks of acidosis.

\section{CONCLUSION}

According to our preliminary results, the GHF was very well accepted by the animals and the trial validated the palatable nature of this fodder introduced into the ration up to $40 \%$ of the fodder requirements. This type of fodder was consumed without impacting the consumption of straw and can replace the consumption of hay since the latter's intake was $70 \%$ lower than the control.

It appears from these tests that the growth performance was improved by using hydroponic green fodder in the feeding of lambs. Therefore, it is recommended for local farmers to use hydroponic barley as an alternative fodder for lambs and other livestock.

It would also be relevant to deepen the tests to determine on the one hand the ideal rate of incorporation of this fodder in the ration and with which other feed it should be associated. On the other hand, to assess whether this fodder can respond to problems of meat quality and the risk of digestive problems, particularly acidosis.

\section{REFERENCES}

Ata M. (2016). Effect of Hydroponic Barley Fodder on Awassi Lambs Performance. Journal of Biology, Agriculture and Healthcare, Vol.6, No.8, pp 60-64.

AOAC. (2000). Official Methods of Analysis. $17^{\text {th }}$ Ed.Association of Official Analytical Chemists, Gaithersburg,MD.

Bhise V., Chavan J. and Kadam S. (1988). Effects of malting on proximate composition and in vitro protein and starch digestibility's of grain sorghum. Journal of Food Science and Technology, 25, pp 327-329.

Cuddeford D. (1989). Hydroponic grass. In Practice 11 (5): pp 211-214. 
Vol. 5, No. 01; 2020

ISSN: $2456-8643$

Chavan J. and Kadam S.S. (1989). Nutritional improvement of cereals by sprouting. Critical Reviews in Food Science and Nutrition, 28: pp 401-437.

Chung T.Y., Nwokolo E.N. and Sim J.S. (1989). Compositional and digestibility changes in sprouted barley and canola seeds. Plant Foods for Human Nutrition, 39: pp 267-278.

Demarquilly C. (1987). Valeur nutritive de l'orge germée. Bulletin Technique, Centre de Recherches Zootechniques et Vétérinaires de Theix, ,(68), pp 19-23.

Fayed A.M. (2011). Comparative study and feed evaluation of sprouted barley grains on rice straw Versus Tamarixmannifera on performance of growing Barki Lambs in Sinai. Journal of American Science, 7: pp 954-961.

Gebremedhin W. (2015). Nutritional benefit and economic value of feeding hydroponically grown maize and barley fodder for Konkan Kanyal goats. IOSR-JAVS, 8 (7), pp 24-30.

Intissar F. A. and Eshtayeh. (2004). A new source of fresh green feed (Hydroponic barley) for Awassi sheep. Master in Environmental Sciences, Faculty of Graduate Studies, An-Najah National University, Nablus, Palestine.

Lorenz K. and D'appaloina B. (1989). Cereal sprouts: composition, nutritive value, food application. CRC Critical reviews in Food Science and Nutrition, 13: pp 353-385.

Miralles-Bruneau M.1 Bigot Ch-E, Benard J-L, Barreira S., Forget D., Grangette D., Grondin S., Michon A., Payet M., Pellier Y, Picard A-M, Picard G-N, Picard J-Ph., Picard T., Reboule JL et Valin D. (2015). Utilisation du fourrage vert hydroponique en production de viande bovine et ovine à la Réunion : une alternative pour pallier aux déficits fourragers futurs liés aux changements climatiques et au manque de foncier agricole ? ARP, Sicarévia, Ovicap, Sedael, Chambre d'Agriculture de la Réunion, AD2R, ARIBEV, Cirad, Urcoopa. Etude financée par l'Etat et l'Union Européenne (Feader) à travers le programme Leader, 85 pages.

Naik P.K., Dhuri R.B., Karunakaran M., Swain B.K. and Singh N.P. (2014). Effect of feeding hydroponics maize fodder on digestibility of nutrients and milk production in lactating cows. Indian Journal of Animal Science, 84: pp 880-883.

Rodriguez M.C., Rodriguez H.E., Ruiz A. O., Flores Grado, J.A. and Arzola C. (2004). Use of green fodder produced in hydroponic system as supplement for lactating cows during the dry season. In: The Proceeding of the American Society of Animal Science, pp: 271-274

Reddy Y.R. (2014). Hydroponic fodder production. http://www.authorstream.com/ Presentation/ kiranreddy526438-2376257-hydroponic-fodderproduction/

Robertson J.B. and Van Soest P.J. (1981). The detergent system of analysis. In: James, W.P.T., Theander, O. (Eds.). The Analysis of Dietary Fiberin Food. Marcel Dekker, NY, pp. 123-158.

Sneath R. and McIntosh F. (2003). On farm review of hydroponic fodder production for beef cattle. Meat and Livestock Australia Limited, pp 1-54.

Van Soest P.J., Robertson J.B. and Lewis B.A. (1991). Methods for dietary fiber, neutral detergent fiber and non-starch polysaccharides in relation to animal nutrition. Journal of Dairy Science, 74 : pp 3583-3597. 